\title{
Impact of Different Washing Conditions on the Release of Ag Species from Textiles
}

\author{
Joanna Kyzioł-Komosińska ${ }^{1,2 *}$, Agnieszka Baran³ ${ }^{3}$ Czesława Rosik-Dulewska1,2, Justyna Czupiol ${ }^{1}$, Sławomir Boncel ${ }^{4}$ and Agnieszka \\ Dzieniszewska ${ }^{1}$ \\ ${ }^{1}$ Institute of Environmental Engineering, Polish Academy of Sciences, 34 M. Skłodowskiej-Curie St., 41-819 Zabrze, Poland \\ ${ }^{2}$ Department of Land Protection, University of Opole, 22 Oleska St., 45-052 Opole, Poland \\ ${ }^{3}$ Faculty of Agriculture and Economics, University of Agriculture, 21 Mickiewicza Av., 31-120 Kraków, Poland \\ ${ }^{4}$ Department of Organic Chemistry, Bioorganic Chemistry and Biotechnology, Silesian University of Technology, 4 Krzywoustego St., $44-100$ Gliwice, Poland
}

\begin{abstract}
The paper investigates the Ag release from textiles (socks available in shops, cotton and viscose filled with Ag nanoparticles-AgNPs) into a washing solution under different conditions. The released $\mathrm{Ag}$ amount depended on various factors, such as test media (chemical composition, temperature and water volume), metal contents, and textile impregnation conditions. Furthermore, it turned out that the textile type and colour were the main parameters affecting the $\mathrm{Ag}$ release. The Ag concentration in the washing solution ranged between $0.015 \mu \mathrm{g} / \mathrm{l}$ and $4.44 \mu \mathrm{g} / \mathrm{l}$ (socks) and between $0.61 \mu \mathrm{g} / \mathrm{l}$ and $103 \mu \mathrm{g} / \mathrm{l}$ (AgNPs-filled cotton). The total Ag percentage released into water during one washing varied considerably among textiles (from less than 1 to $34 \%$ ). In the tap water presence, the released Ag load decreased from 6.82 to $1.35 \mu \mathrm{g} / \mathrm{l}$ due to the $\mathrm{AgCl}$ and/or $\mathrm{Ag}_{2} \mathrm{CO}_{3}$ precipitation. The bleaching process had a strong effect on the quality and speciation of $\mathrm{Ag}$ rleased during the washing process. For example, the $\mathrm{Ag}$ concentration in the washing solution changed from $0.8 \mu \mathrm{g} / \mathrm{l}$ to $12.9 \mu \mathrm{g} / \mathrm{l}$ and was higher by 20 times (white socks) to 170 times (black socks) when compared with washing in water without any oxidising agent.

The washing of nano-Ag-treated textiles may have potentially released both ionic and particle forms as smaller AgNPs dissolved more rapidly than large AgNPs. The results of the present study demonstrate that the water solution containing Ag revealed a toxic effect on $D$. magna and $V$. fischeri. Among the tested species, $D$. magna was the most sensitive and revealed acute toxicity for low EC50 values. The $V$. fischeri response was less sensitive due to the physiological state of the bacteria.
\end{abstract}

Keywords: Nano-silver-filled textiles; Socks; Silver nanoparticles; Toxicity; Washing process

Abbreviations: AgNPs: Silver Nanoparticles; EC50: Half Maximal Effective Concentration; DI: Deionized Water; TOC: Total Organic Carbon; TU: Toxic Unit; D. magna: Daphnia magna; V. fischeri: Vibrio fischeri

\section{Introduction}

Due to the rapid nanotechnology progress and the expanding nanomaterial range (nanometals, nanometal oxides) having been produced and developed since the beginning of the $21^{\text {st }}$ century, it is essential to take the potential nanomaterial impacts on humans and environment into consideration. A nanomaterial (material in nanoscale) is a material intentionally produced in the nanoscale so that it could have a specific property or composition [1]. Nanoparticles are clusters of atoms in the size range of $1-100 \mathrm{~nm}$ in at least one dimension. The metallic nanoparticles $(\mathrm{Ag}, \mathrm{Au}, \mathrm{Cu}$ and $\mathrm{Zn}$ ) are the most promising agents. They demonstrate unique and considerably changed physical, chemical and biological properties when compared to their macroscale counterparts and dissolved salts. Such a situation is related to the fact that nanoparticles demonstrate high surface-tovolume ratio. Characteristic colour of noble metals in colloidal form (yellow for silver and red for gold) when compared with the colourless Ag ionic form has been used in the artistic glass dyeing since the $19^{\text {th }}$ century, when the "nano" nomenclature was not known yet.

The nanoparticles are interesting for various applications (such as catalysts, optical sensing, antibacterial activity or data storage). Due to the nanometal properties, an increasing number of consumer and medical products is being used nowadays in Asia, North America and Europe. On the other hand, the nanoparticle properties pose problems to be faced by nanotechnology. The Ag nanoparticles (AgNPs) are one of the most widely used nanometals. They are present in over
250 consumer products, including domestic devices (fridges, vacuum cleaners, air conditioning), paints and varnish, textiles/textiles and clothes (sportswear, T-shirts and socks), plastics, cosmetics and detergents, or medical products (surgical gowns, dressing bandages, catheters, infusion systems, medical textiles) [2-4].

According to the Woodrow Wilson Database [5], creams and cosmetic items (32.4\%), health supplements (4.1\%), textiles and clothing $(18.0 \%)$, air and water filters (12.3\%), household items $(16.4 \%)$ and detergents $(8.2 \%)$ are the most important groups of products containing AgNPs. One of the AgNP applications is enhancing the antibacterial textile properties. Apart from consumer products containing AgNPs, the nanosized Ag colloidal solutions are available on sale. The solutions allow consumers to prepare antimicrobial textiles which may be used in kitchens, bathrooms, etc. AgNPs are used either to protect the products from the microbial growth effects or to protect the user from harmful microorganisms. AgNPs are effective against 650 disease-causing organisms in the body [6], even at low concentration levels $\left(<10^{-7} \mathrm{~g} / \mathrm{l}\right)$, and relatively non-toxic for human cells. Due to the increased production of Ag-filled textiles, these materials are one of the major sources of the AgNP release into the environment. During washing, abrading, or discarding of the AgNPs-containing products,

*Corresponding author: Joanna Kyzioł-Komosińska, Institute of Environmenta Engineering, Polish Academy of Sciences, 34 M. Skłodowskiej-Curie St., 41-819 Zabrze Poland, Tel: +48 3227164 81; E-mail: joanna.kyziol-komosinska@ipis.zabrze.pl

Received May 17, 2016; Accepted May 23, 2016; Published May 25, 2016

Citation: Kyzioł-Komosińska J, Baran A, Rosik-Dulewska C, Czupiol J, Boncel S et al. (2016) Impact of Different Washing Conditions on the Release of Ag Species from Textiles. J Civil Environ Eng 6: 234. doi:10.4172/2165-784X.1000234

Copyright: (c) 2016 Kyzioł-Komosińska J, et al. This is an open-access article distributed under the terms of the Creative Commons Attribution License, which permits unrestricted use, distribution, and reproduction in any medium, provided the original author and source are credited. 
Ag can easily release into wastewater and enrich the wastewater stream with Ag. Subsequently, Ag is transported into a wastewater treatment facility and ends up in surface water bodies which may be used as drinking water sources $[7,8]$. Ag may also deposit in the river sediments and soil, where it can stay for a long time or be absorbed by biological organisms. Therefore, Ag can act as eco-toxicological hazard; undergo biodegradation or bioaccumulate in the food chain [9]. Moreover, AgNPs may potentially disrupt helpful bacteria used in the wastewater treatment facilities or jeopardize aquatic organisms [10].

$\mathrm{Ag}$ can be introduced into the environment as nanoparticles, nanoparticle aggregates, or soluble ions [8]. Under oxidizing conditions, nano-Ag is found in fresh water in insoluble salts (bromides, chlorides and iodides). Under reducing conditions, Ag exists as a free metal. When the environment is rich in sulphur (organic thiol groups and inorganic sulphides), as during sedimentation processes in the wastewater treatment, the nanosize Ag sulphides are formed [11]. AgNPs and their derivatives may destroy and/or pass through the cell membrane and bind with the $-\mathrm{SH}$ groups in the cellular enzymes. Consequently, they decrease the enzymatic activity, which may change the metabolism of microorganisms, inhibit their growth and lead to the cell death $[12,13]$. The risk posed by AgNPs has not been clarified yet. Their widespread use could increase the Ag release in the environment, which may have a negative impact on ecosystems. The recent results of the acute toxicity tests support the theory that the AgNP effects on the aquatic organisms are mainly due to the $\mathrm{Ag}^{+}$release from nanoparticles [14]. Therefore, the Ag release from products into water or wastewater should be controlled. In North America in 2008, the AgNP concentration in surface water was at the level of nanogram per liter [15]. The AgNP concentration in wastewater was assessed to be 3 orders of magnitude higher. The background Ag concentrations in pristine waters were 0.01 $\mathrm{mg} / \mathrm{l}[10]$. The World Health Organization recommended the exposure limits for Ag compounds in drinking water at the level of $0.10 \mathrm{mg} / \mathrm{l} \mathrm{[16].}$

The American Conference of Governmental Industrial Hygienists established separate threshold limit values for the metallic $\mathrm{Ag}(0.1 \mathrm{mg} /$ $\left.\mathrm{m}^{3}\right)$ and soluble $\mathrm{Ag}$ compounds $\left(0.01 \mathrm{mg} / \mathrm{m}^{3}\right)$. On the other hand, the permissible exposure limit (PEL) recommended by the Occupational Safety and Health Administration and the Mine Safety and Health Administration and the recommended exposure limit set by the National Institute for Occupational Safety and Health are established at the level of $0.01 \mathrm{mg} / \mathrm{m}^{3}$ for all the Ag forms [17].

Many works on the Ag nanoparticles focus on the AgNP synthesis (including physical, chemical, and biological methods) and antibacterial activity of textiles [18-21]. There is still no information on the concentrations of Ag particles that may be released from textile products with $\mathrm{Ag}$ in their life cycle (especially when it comes to the release into the water environment during washing processes). The Ag release from different textiles and dependence between different washing conditions and $\mathrm{Ag}$ leaching have been discussed in a small number of studies $[8,22,23]$. Importantly, the type of chemical Ag species released during washing of textiles filled with AgNPs remains unclear [23-25]. Having the above-mentioned aspects in mind, the aim of this paper was to quantify the Ag release from commercially available socks containing AgNPs, and from cotton and viscose textiles filled with AgNPs under different conditions. The research was to take into account the washing medium kind (deionized and tap water), washing temperature $\left(40^{\circ} \mathrm{C}, 60^{\circ} \mathrm{C}, 90^{\circ} \mathrm{C}\right.$ ), and presence of oxidizing agents. Additionally, the chemical species of the released Ag were detected in the washing solution. Due to the toxicity of the washing solutions containing Ag, toxicity tests were applied.

\section{Material and Methods}

\section{Materials}

The following materials were used in the experiment:

1. Socks with AgNPs available in the market (different colours and fibre composition); two pairs of socks had Ag mentioned on the label and three pairs of socks contained Ag in undeclared amounts;

2. AgNPs-filled cotton and viscose were prepared in a laboratory. The textiles were saturated with different Ag concentrations at different contact times of AgNPs-solution with textiles.

\section{Sock textile characteristics}

1. White colour - Hong Kong manufacturer; composition: cotton $70 \%$, polyester $27 \%$, lycra $3 \%$, undeclared amounts of AgNPs;

2. Ecru colour - Polish manufacturer; composition: cotton 55\%, lyocell with sea algae $23 \%$, polyamide $19 \%$, lycra (polyurethane) $3 \%$, declared amount of AgNPs;

3. Grey colour - Polish manufacturer; composition: cotton 55\%, lyocell with sea algae $23 \%$, polyamide $19 \%$, lycra (polyurethane) 3\%, declared amount of AgNPs;

4. Graphite colour - Polish manufacturer; composition: cotton $55 \%$, lyocell with sea algae $23 \%$, polyamide $19 \%$, lycra (polyurethane) $3 \%$, declared amount of AgNPs;

5. Black colour - Hong Kong manufacturer; composition: cotton $70 \%$, polyester $27 \%$, lycra $3 \%$, undeclared amounts of AgNPs.

\section{Laboratory Preparation of Textiles Containing AgNPs}

The AgNPs-filled cotton and viscose preparation process was conducted at room temperature $\left(25 \pm 2^{\circ} \mathrm{C}\right)$ and under normal pressure in a water solution without any extra reducing agents. The textiles were prepared according to following procedure: cotton and viscose textiles $(10 \mathrm{x} 15 \mathrm{~cm} ; 5 \mathrm{~g})$ were put into plastic boxes with $0.75 \mathrm{l}$ of working solutions containing 4 different of AgNP concentrations (1, 5, 25 and 50 $\mathrm{mg} / \mathrm{l})$. The contact times were 15 and $60 \mathrm{~min}$, respectively. Afterwards, the textile samples were separated from the solution and dried for 1 day at room temperature. The working AgNP solution was obtained with the serial dilution of the stock solution with deionized (DI) water. The stock solution was a commercial AgNP solution with the following properties: $\mathrm{pH}-6.95$; Eh- $106 \mathrm{mV}$; conductivity- $24 \mu \mathrm{S} / \mathrm{cm}$; AgNP concentration- $140 \mathrm{mg} / \mathrm{l}$; particle size- 8-18 nm (High Performance Particle Sizer model HPP5001, MALVERN Instruments (Figure 1). It contained the following reducing agents: acetic acid $(83.02 \mathrm{mg} / \mathrm{l})$ and propionic acid $(32.18 \mathrm{mg} / \mathrm{l})$. The organic acids with carboxylic ($\mathrm{COOH}$ ) groups provided the reducing conditions and stabilization of the AgNP forms. They also prevented the AgNP oxidisation to $\mathrm{Ag}^{+}$. The presence of nano-Ag particles in the solution was confirmed with the transmission electron microscope analysis (TECNAI F20 TWIN, FEI Company; Figure 2). The particles were spherical and monodisperse.

\section{Analytical Method}

\section{Measurement of total Ag content in textile samples}

Socks, cotton and viscose textiles loaded with AgNPs were cut into squares $(0.5 \times 0.5 \mathrm{~cm})$ with scissors. Afterwards, the samples underwent either wet or thermal mineralization. The wet mineralization (acid digestion) is based on the oxidizing action of strong acids, e.g. nitric acid $\left(\mathrm{HNO}_{3}\right)$. The digestion method (EPA SW846 Method 3050B) described by Benn and Westerhoff [8] was used for the textile degradation and Ag release into the solution. 


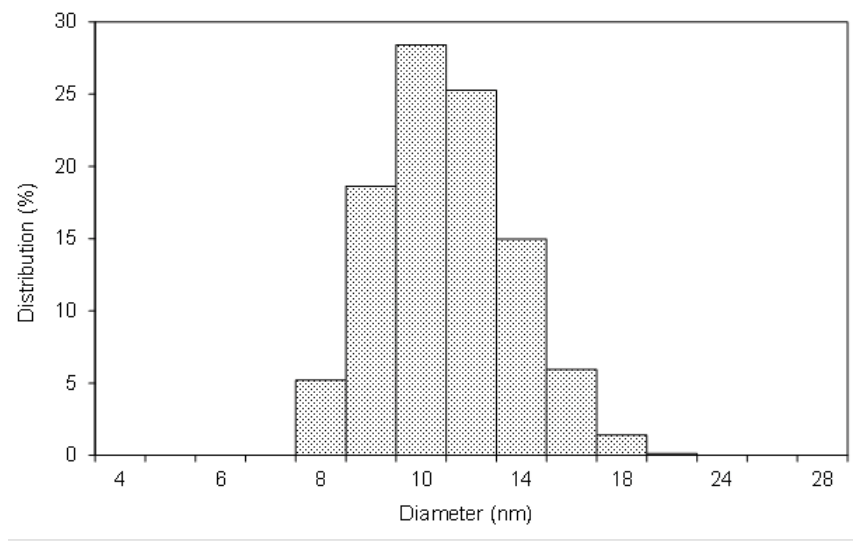

Figure 1: Distribution of AgNP sizes in the stock solution.

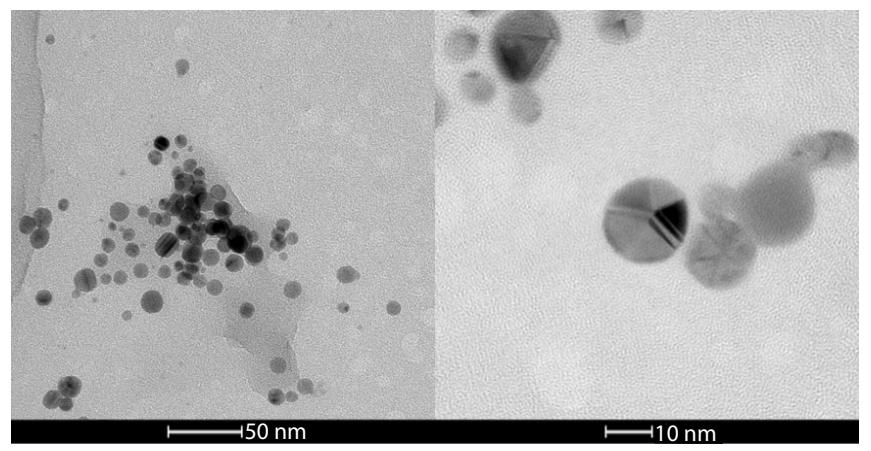

Figure 2: Transmission electron microscope image of AgNPs in the stock solution.

On the other hand, the samples were ashed in quartz crucibles in a programmable muffle furnace at $550^{\circ} \mathrm{C}$ for 2 hours in the thermal digestion process. The remaining substance (powder) was put in 100 ml volumetric flasks, to which $4 \mathrm{ml}$ of concentrated $\mathrm{HNO}_{3}$ was added. The flasks were heated in a sand bath at $135^{\circ} \mathrm{C}$. Subsequently, the solution was cooled and filled up with DI water. All the experiments were conducted in triplicate.

\section{The Ag release from textiles}

Socks, cotton and viscose textiles loaded with AgNPs were cut into squares $(1 \times 1 \mathrm{~cm})$, placed in a glass bottle with water and washed in a water bath under different conditions for 1 hour, stirring every 10 minutes, without detergents. The textile samples were then separated from the solution and dried. After washing, the solution was stored in polypropylene vials in dark at room temperature. It was collected for the analysis. The total $\mathrm{Ag}$ concentration and $\mathrm{pH}$ were determined in the solutions. The released Ag concentration was determined in an unfiltered solution which was filtered through Whatman's cellulose nitrate membranes $(0.1 \mu \mathrm{m})$.

\section{Ag concentration determination}

The Elan 6100 DRC-e ICP-MS spectrometer (Perkin Elmer) was used for quantitative analyses of the total $\mathrm{Ag}$ content in all the samples (socks and AgNPs-filled textiles) and Ag concentration released into the solution during washing process conducted under different conditions. The apparatus was equipped with a standard ICP quartz torch, cross-flow nebulizer and nickel cones. Samples and standards were delivered with a peristaltic pump. The spectrometer was optimized daily, to provide maximum intensity for ${ }^{24} \mathrm{Mg},{ }^{115} \mathrm{In},{ }^{238} \mathrm{U}$ and minimum values for $\mathrm{CeO} / \mathrm{Ce}$ (less than $3 \%$ ) and $\mathrm{Ba}^{2+} / \mathrm{Ba}$ (less than $3 \%$ ), with a $10 \mu \mathrm{g} / \mathrm{l}$ solution $(\mathrm{Mg}, \mathrm{Cu}, \mathrm{Rh}, \mathrm{Cd}, \mathrm{In}, \mathrm{Ba}, \mathrm{Ce}, \mathrm{Pb}, \mathrm{U})$ in $1 \% \mathrm{HNO}_{3}$ Elan 6100 Setup/Stab./Masscal Solution (Perkin Elmer). The ${ }^{107} \mathrm{Ag}$ concentrations were measured with the internal ${ }^{103} \mathrm{Rh}$ standard. The higher Ag contents in the solutions were determined with the flame atomic absorption spectrometry Avanta (PM) spectrometer (GBC) with a hollow Ag cathode lamp at $\lambda=328.1 \mathrm{~nm}$. The air-acetylene flame was used for atomization. The solutions obtained from the washing of AgNPs-filled cotton and viscose (initial AgNP concentrations: 25 and $50 \mathrm{mg} / \mathrm{l}$ ) were used to determine the $\mathrm{Ag}^{+}$concentration with the potentiometric method. To do that, the CPI 505- Elmetron Poland ionometr (equipped with the EPS-1 glass-combined electrode and silver EAg/S-01 electrode) was used. The chloride half-cell was used for reference. The method detection limit was $0.01 \mathrm{mg} / \mathrm{l}$. $\mathrm{pH}$ was measured with a $\mathrm{pH}$-meter equipped with a glass-combined electrode.

The Ag content in each textile was normalized with respect to the textile dry weight and solution volume.

Different experiment conditions were taken into consideration for the Ag release:

1. Temperature effect: Ag was released from the textiles at 40,60 and $90^{\circ} \mathrm{C}$.

2. Water volume effect: the Ag content released from textiles was investigated (textile mass: water volume ratio of 1:100 and of 1:500; i.e. $0.5 \mathrm{~g}$ of textile $+50 \mathrm{ml}$ water and $0.5 \mathrm{~g}$ of textile $+250 \mathrm{ml}$ of water, respectively).

3. Water chemistry effect: Ag was released in the presence of deionized (DI) water and tap water. DI water $(\mathrm{pH}-5.86$; Eh- 181 $\mathrm{mV}$; conductivity- $7.02 \mu \mathrm{S} / \mathrm{cm}$ ) came from the Millipore Milli-Q water purification system and was used to prepare all the aqueous solutions. Tap water ( $\mathrm{pH}-7.27$; Eh- $238 \mathrm{mV}$; conductivity- 941 $\mu \mathrm{S} / \mathrm{cm}$; alkalinity- $4.6 \mathrm{eq} / \mathrm{l} ; \mathrm{Na}^{+} 7.6 \mathrm{mg} / \mathrm{l} ; \mathrm{K}^{+} 1.6 \mathrm{mg} / \mathrm{l} ; \mathrm{Ca}^{2+} 89 \mathrm{mg} / \mathrm{l} ;$ $\left.\mathrm{Mg}^{2+} 27 \mathrm{mg} / \mathrm{l} ; \mathrm{Cl}^{-} 30 \mathrm{mg} / \mathrm{l} ; \mathrm{SO}_{4}{ }^{2-} 64 \mathrm{mg} / \mathrm{l} ; \mathrm{HCO}_{3}-280.68 \mathrm{mg} / \mathrm{l}\right)$ was used for the Ag release under real conditions. The cation and anion concentrations were measured with the Metrohm ion chromatograph (Herisau Metrohm AG) equipped with the MetroSep A Supp 5 column (for anions) or Metrosep C2 column (for cations). The $\mathrm{HCO}_{3}^{-}$amount was calculated on the basis of alkalinity and $\mathrm{pH}$.

4. Bleaching agent presence effect in $1 \%$ concentration $(5.0 \mathrm{ml}$ for $500 \mathrm{ml}$ of water bath; $\mathrm{pH}-4.97$; Eh- $360 \mathrm{mV}$ ). The bleaching agent level was similar as the level used under household conditions. The composition was: $5-15 \%$ of the oxygen-based bleaching agent, non-ionic and anionic surfactants and $<5 \%$ Hexyl Cinnamal fragrance (as indicated in the characteristics). The oxygen-based bleaching agent contained sodium per carbonate $\left(2 \mathrm{Na}_{2} \mathrm{CO}_{3} 3 \mathrm{H}_{2} \mathrm{O}_{2}\right)$. In water, sodium per carbonate breaks down into sodium carbonate and hydrogen peroxide:

$2 \mathrm{Na}_{2} \mathrm{CO}_{3} \cdot 3 \mathrm{H}_{2} \mathrm{O}_{2(\text { aq })} \rightarrow 2 \mathrm{Na}_{2} \mathrm{CO}_{3(\text { aq })}+3 \mathrm{H}_{2} \mathrm{O}_{2 \text { (aq) }}$

Hydrogen peroxide is the active oxidizing agent - it decomposes to oxygen gas:

$$
2 \mathrm{H}_{2} \mathrm{O}_{2} \rightarrow \mathrm{H}_{2} \mathrm{O}+\mathrm{O}_{2}
$$

In the solution (white sock washing in the presence of a bleaching agent), total organic carbon (TOC) values were determined with the TOC 5000A Analyser (Shimadzu). The TOC values were given after taking into account the blank control for the water + bleaching agent solution, which was $251.5 \mathrm{mgC} / \mathrm{l}$. 
5. Textile type effect: the Ag release from AgNPs-filled cotton and viscose was carried out at textile: DI water ratio $(1: 500)$ and at $20^{\circ} \mathrm{C}$, $40^{\circ} \mathrm{C}, 60^{\circ} \mathrm{C}$ and $90^{\circ} \mathrm{C}$

\section{Antibacterial activity - Eco-toxicity test}

The acute toxicity assessment of water solution containing Ag (obtained after washing) was performed with the following toxicity tests: Daphtoxkit F Magna and Microtox. Both tests are the most internationally used bioassays for the toxicity screening of chemicals and for toxicity monitoring of effluents and contaminated waters [2630]. The crustacean acute toxicity was assessed through determining the inhibition of the D. magna mobility. The 24-h immobilization of $D$. magna bioassays was performed according to the Standard Operational Procedures of Daphtoxkit F Magna [31]. The Microtox test was used to assess the inhibition of luminescence in the $V$. fischeri bacteria [32]. The measurement analysis of the change in the luminescence was performed with the Microtox M500 Analyser. The standard test protocol was applied for water samples: $81.9 \%$ basic test (basic test, MicrotoxOmni software was used). The luminescence measurement was carried out before and after the 15-min incubation of the bacterial suspension with the studied sample. Three replicate samples were tested. The toxicity results were expressed as Effective Concentration (EC50 value), defined as the sample concentration that would produce a $50 \%$ reduction in the $V$. fischeri luminescence or $50 \%$ of the D. magna immobilization. The EC50 values were converted to Toxic Units (TU), according to the formula TU=1/EC50. The risk assessment system developed by Persoone et al. [33] was used to assess the water obtained after sock washing in terms of toxicity. Finally, the results were classified: class I: TU $\leq 0.4$ no significant toxic effect, no acute hazard; class II: $0.4<\mathrm{TU} \leq 1$ significantly toxic effect, low acute hazard; class III: $1<\mathrm{TU} \leq 10$ significantly toxic effect, acute hazard; class IV: $10<\mathrm{TU} \leq 100$ high acute hazard; class $\mathrm{V}$ : $\mathrm{TU}>100$ very high acute hazard.

\section{Results and Discussion}

\section{Total Ag content in sock samples}

Regardless of the fact whether the Ag content was declared on the label or not, large Ag amounts were found in the investigated socks. The total Ag content in the studied socks (available in the Polish market) ranged from 8.232 to $20.94 \mathrm{mg} / \mathrm{kg}$ (Table 1). The Ag content in textiles was within the range observed by other authors. It was broad and changed between 1 and $>1,000 \mathrm{mg} / \mathrm{kg}$ (Table 2). There were no statistically significant differences between the Ag content obtained during the wet and dry mineralization procedures (Table 1). Consequently, it was decided to take the Ag content obtained in the dry mineralization into account for further calculations.

\section{Total Ag content in AgNPs-filled textiles}

The total Ag content in the AgNPs-filled cotton and viscose mainly depended on: metal concentration in the solution used to prepare the antibacterial material, contact time for the textile and Ag solution, and textile type. Furthermore, the mineralization mode was an important parameter affecting the textile decomposition (Figure 3).

During the wet mineralization, the Ag content in the cotton samples changed from 3.99 to $148.11 \mathrm{mg} / \mathrm{kg}$ at 15 -min contact time and for the viscose samples, the $\mathrm{Ag}$ content increased from 7.3 to $231.24 \mathrm{mg} / \mathrm{kg}$ (samples 1/15-50/15), whereas the initial concentration in the solution increased from 1 to $50 \mathrm{mg} / \mathrm{l}$. The contact time prolongation by 4 times (to $60 \mathrm{~min}$ ) for the solution with the AgNP textile resulted in the $\mathrm{Ag}$ content increase in textiles from 4.959 and $156.39 \mathrm{mg} / \mathrm{kg}$ and from 7.68 to $253.77 \mathrm{mg} / \mathrm{kg}$ (samples $1 / 60-50 / 60$ ), respectively. Due to the digestion with sample ashing in the oven and the remnant dissolution in the nitric acid solution (thermal decomposition), the total Ag content was higher in all the samples than after the wet mineralization. For the cotton samples, the value ranged between 4.748 and $161.66 \mathrm{mg} / \mathrm{kg}$ (15-min contact time) and between 5.756 and $182.08 \mathrm{mg} / \mathrm{kg}(60-\mathrm{min}$ contact time). For the viscose samples, the values were 8.941-295.82 $\mathrm{mg} / \mathrm{kg}$ and $8.847-304.96 \mathrm{mg} / \mathrm{kg}$, respectively.

Viscose bound higher total $\mathrm{Ag}$ amounts than cotton in the entire initial Ag concentration range in the solution. Furthermore, the total $\mathrm{Ag}$ content increase observed for viscose during the dry mineralization was $15-28 \%$ in comparison with the wet mineralization. The value for cotton was $10-15 \%$. The obtained results indicate stronger Ag binding with the surface functional groups in viscose (Figure 3).

During the textile preparation, the functional groups occurring on the cotton and viscose fibre surfaces bound the AgNPs efficiently, which facilitated the particle adsorption [34-36]. The SEM analysis (Figure 4) revealed small particles with different, non-homogenous distribution on the Ag-filled cotton and viscose fibres. The nanoparticles were clearly visible as white spots. For the AgNP concentrations of $1 \mathrm{mg} / \mathrm{l}$ and $50 \mathrm{mg} / \mathrm{l}$ on cotton and viscose, good distribution was discerned along the fibres (on their surface). The results indicated that Ag bound with fibres in the particle form. Cellulose is the main cotton and

\begin{tabular}{|c|c|c|c|c|c|}
\hline Sock & White & Ecru & Grey & Graphite & Black \\
\hline \multirow{2}{*}{ Wet mineralization } & $13.643 \pm$ & $20.938 \pm$ & $8.232 \pm$ & $16.810 \pm$ & $16.102 \pm$ \\
& 0.320 & 0.465 & 0.136 & 0.378 & 0.411 \\
\hline \multirow{2}{*}{ Thermal digestion } & $13.825 \pm$ & $21.231 \pm$ & $8.540 \pm$ & $16.980 \pm$ & $16.380 \pm$ \\
& 0.145 & 0.265 & 0.111 & 0.210 & 0.256 \\
\hline
\end{tabular}

Table 1: Total Ag content $(\mathrm{mg} / \mathrm{kg})$ in socks after mineralization.

\begin{tabular}{|c|c|c|}
\hline Textile types & Ag content & References \\
\hline $\begin{array}{c}\text { 8 socks and one pair of trousers at } \\
\text { varying proportions of natural fibres or } \\
\text { only synthetic }\end{array}$ & $\begin{array}{c}1.5-2,925 \text { and } \\
\text { one without detectable } \\
\mathrm{Ag}\end{array}$ & {$[34]$} \\
\hline Nine socks with different compositions & $0.003-21.6$ & {$[22]$} \\
\hline Textiles & $0.9-1,358$ & {$[8]$} \\
\hline Textiles & $30-270$ & {$[23]$} \\
\hline Textiles & $0.99-15.1$ & {$[35]$} \\
\hline Socks available in the Polish market & $8.23-20.94$ & This paper \\
\hline Cotton filled with nAg & $4.959-182.08$ & This paper \\
\hline Viscose filled with nAg & $7.68-304.96$ & This paper \\
\hline
\end{tabular}

Table 2: Total Ag content in available textiles (mg/kg).

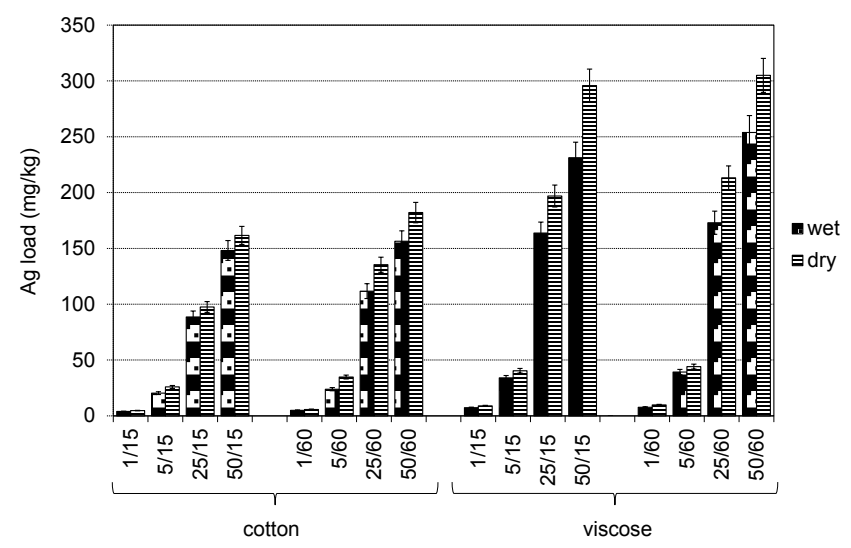

Figure 3: Ag contents in cotton and viscose samples with wet and dry mineralization (sample description - AgNPs initial concentration in solution (mg/l)/contact time (min). 
viscose component. Cellulose makes $90-96 \%$ of cotton (based on the fibre weight) with $\beta(1 \rightarrow 4)$ linked $\mathrm{D}$-glucose units $\left(\mathrm{C}_{6} \mathrm{H}_{10} \mathrm{O}_{5}\right)_{n}$. It has an extensive surface area with functional hydroxyl $(-\mathrm{OH})$ groups [37]. During the production of viscose (fibres of regenerated cellulose), a variety of plants (such as soy, bamboo or sugar cane) interacts with strong reagents, which reduces the polymerization degree and average number of glucose units in the cellulose polymer chain and increases the number of surface hydroxyl $(-\mathrm{OH})$ groups and greater viscose reactivity (in comparison with cotton) [38] (Figure 5). The surface hydroxyl groups contribute to the increase in the number of the $\mathrm{Ag}$ particles bound by viscose.

\section{AgNP release from socks}

Temperature and water volume effects: During the washing process, Ag was removed from the textile fibres into the solution. The released Ag amount depended on the volume of used water and its temperature. When the DI water was used and the applied textile mass: water volume ratio was 1:100, it was observed that the Ag release depended on the applied water temperature and sock type (particularly its colour). The laboratory research revealed that the Ag amount released from light colour socks (white and ecru) was higher than from the dark ones (grey, graphite, black). The highest Ag concentration in the solution in the washing was observed for water at $40^{\circ} \mathrm{C}$ for all the samples. It ranged from 4.441/4.295 $\mu \mathrm{g} / \mathrm{l}$ (white/ecru socks) to 0.5255 $\mu \mathrm{g} / \mathrm{l}$ (black socks). The released Ag loads were $0.4441 / 0.4295 \mathrm{mg} / \mathrm{kg}-$ $0.05255 \mathrm{mg} / \mathrm{kg}$, respectively. In comparison with the total Ag content in the socks, the Ag removal percentage changed from $3.26 \%$ (white socks) to $0.33 \%$ (black socks). The results indicate that the surface functional groups had a strong effect on the Ag release from textiles as the AgNPs are bound on the fibres due to the interaction with the surface functional groups. The surface functional groups originated from the cotton fibres. The surface functional groups may have also come from the dyes, which additionally increased their amount on the
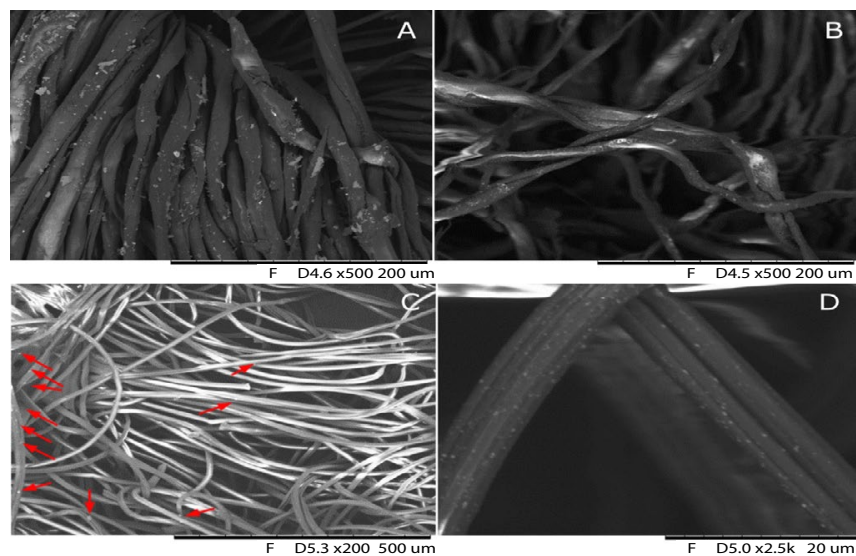

Figure 4: Cotton $(A$ and $B)$ and viscose $(C$ and $D)$ fibres after impregnation in a bath with $1 \mathrm{mg} / \mathrm{AgNPs}(A$ and $C$ ) and $50 \mathrm{mg} / \mathrm{AgNPs}(B$ and $D)$.

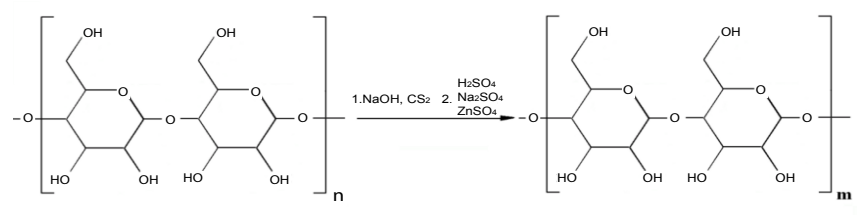

$n>m$

Figure 5: Diagram of the cellulose transformation process. colourful textile surfaces and also increased the textile ability to bind $\mathrm{Ag}$ and decrease its ability to release Ag. The application of higher washing temperature $\left(60^{\circ} \mathrm{C}\right.$ and $\left.90^{\circ} \mathrm{C}\right)$ resulted in the decrease of the $\mathrm{Ag}$ released into the solution in the concentration range of 3.410-0.113 $\mu \mathrm{g} / \mathrm{l}$ and $1.775-0.059 \mu \mathrm{g} / \mathrm{l}$, respectively. The values corresponded to the Ag load of $0.311-0.0113 \mathrm{mg} / \mathrm{kg}$ and $0.1775-0.0059 \mathrm{mg} / \mathrm{kg}$ as well as to released Ag percentage vs. total Ag of $2.07-0.0702 \%$ and $1.3-0.0367 \%$ (Figure 6). When the volume of water for washing was increased 5 times (textile mass: water volume ratio of 1:500), the released $\mathrm{Ag}$ concentration was lower in the solution. At the same time, the released Ag load and Ag removal percentage from socks increased. The temperature and sock type influence was the same as for the lower water volume. The released $\mathrm{Ag}$ concentration in the solution was the highest for the white and ecru socks (at $40^{\circ} \mathrm{C} 3.96$ and $3.30 \mu \mathrm{g} / \mathrm{l}$, respectively). The released $\mathrm{Ag}$ load was 1.980 and $1.651 \mathrm{mg} / \mathrm{kg}$, respectively. The Ag concentration after washing the grey, graphite and black socks was much lower. The values were $0.920,0.853$ and $0.432 \mu \mathrm{g} / \mathrm{l}$, respectively. The released $\mathrm{Ag}$ load was $0.4600,0.4268$ and $0.2157 \mathrm{mg} / \mathrm{kg}$, respectively (Figure 6). The released Ag percentage vs. total Ag in socks ranged from $14.52 \%$ (white socks) and $1.34 \%$ (black socks). When the samples were washed at 60 and $90^{\circ} \mathrm{C}$, the $\mathrm{Ag}$ concentration in the solution was lower (2.54-0.063 $\mu \mathrm{g} / \mathrm{l}$ and $0.550-0.015 \mu \mathrm{g} / \mathrm{l}$, respectively). The released Ag load was 1.27 $0.0313 \mathrm{mg} / \mathrm{kg}$ and $0.275-0.007 \mathrm{mg} / \mathrm{kg}$, respectively. Regardless of the volume, all the washing liquids had $\mathrm{pH}$ of $6.08-7.05$. In the washing solutions, the $\mathrm{Ag}^{+}$concentration in the samples was lower than the limit of quantification in the potentiometric method $(0.01 \mathrm{mg} / \mathrm{l})$. For that reason, the ionic Ag could not be determined in the solution.

Upto $98 \%$ of the released $\mathrm{Ag}$ was able to penetrate $0.1-\mu \mathrm{m}$ filters. The results show that the particle size was less than $0.1 \mu \mathrm{m}$. Therefore, Ag occurred in the solution either as small nanoparticles or in the dissolved form as $\mathrm{Ag}^{+}$. The study of Benn and Westerhoff [8] showed that during the washing of $\mathrm{Ag}$-containing commercial socks in distilled water, up to $86 \%$ of $\mathrm{Ag}$ was released in the ionic form. The activity of nano-Ag vs. oxygen is well known. When AgNPs contacted with air and water, the $\mathrm{Ag}^{+}$ions formed during the washing of the AgNPs-filled textiles [39].

\section{Water chemical composition effect}

The effect of the water chemical composition on the Ag release from socks was investigated for DI and tap water in the batch system at $40^{\circ} \mathrm{C}$ at textile mass: water volume ratios of $1: 100$ and 1:500. The results showed that the chemical composition of water (together with the total Ag content and strength binding AgNPs on the fibre surfaces) had a significant role in the Ag release from textiles. When tap water was used for washing, both the concentration and loads of the released AgNPs decreased (Figure 7). The situation was observed for all the sock types. The Ag concentration in the tap water (textile mass: water mass $=1: 100$ ) ranged from $1.54 \mu \mathrm{g} / \mathrm{l}$ (white socks) to $0.38 \mu \mathrm{g} / \mathrm{l}$ (black socks). In the DI water, the Ag concentrations ranged from $4.445 \mu \mathrm{g} / \mathrm{l}$ to $0.525 \mu \mathrm{g} / \mathrm{l}$, respectively. When the textile mass: tap water volume ratio was $1: 500$, the released $\mathrm{Ag}$ concentration was between $0.58 \mu \mathrm{g} / \mathrm{l}$ and $0.32 \mu \mathrm{g} / \mathrm{l}$. For the DI water, it increased from $3.96 \mu \mathrm{g} / \mathrm{l}$ to $0.432 \mu \mathrm{g} / \mathrm{l}$, respectively. In the tap water presence and at sock mass: water volume ratio of 1:100, the released Ag loads decreased by 3.83-2.8 times (light colour socks) and by $1.79-1.38$ (dark socks). When the discussed ratio was 1:500, the values changed by $6.82-4.29$ (light colour socks) and by $2.24-1.35$ times (dark socks). When Ag was released in the DI water presence, the $\mathrm{pH}$ value was approx. 6.69. In the tap water presence, $\mathrm{pH}$ was 8.15 to 7.67. The chemical analysis of tap water showed high conductivity (941 $\mu \mathrm{S} / \mathrm{cm})$ and the of $\mathrm{Cl}^{-}$ion presence in water $(30 \mathrm{mg} / \mathrm{l})$. In the presence of the $\mathrm{Cl}^{-}$ions, $\mathrm{AgCl}$ can be precipitated because the salt solubility is 
A

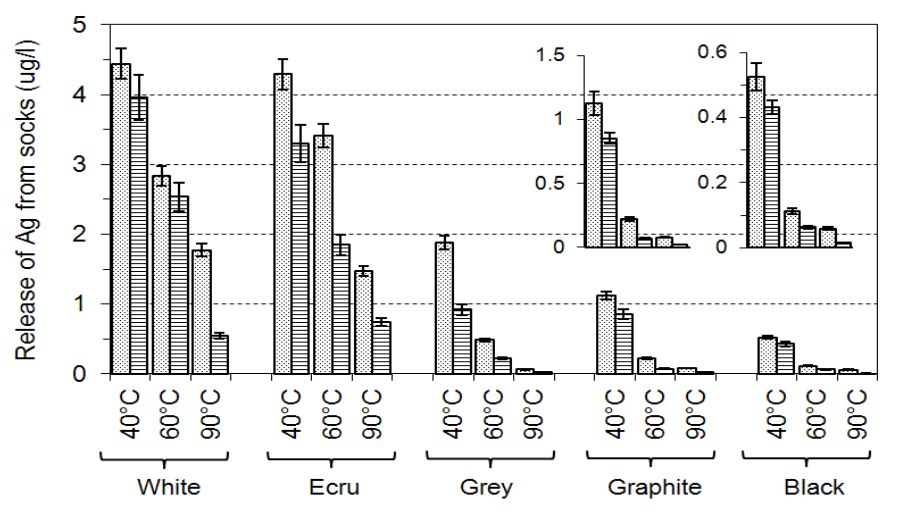

B

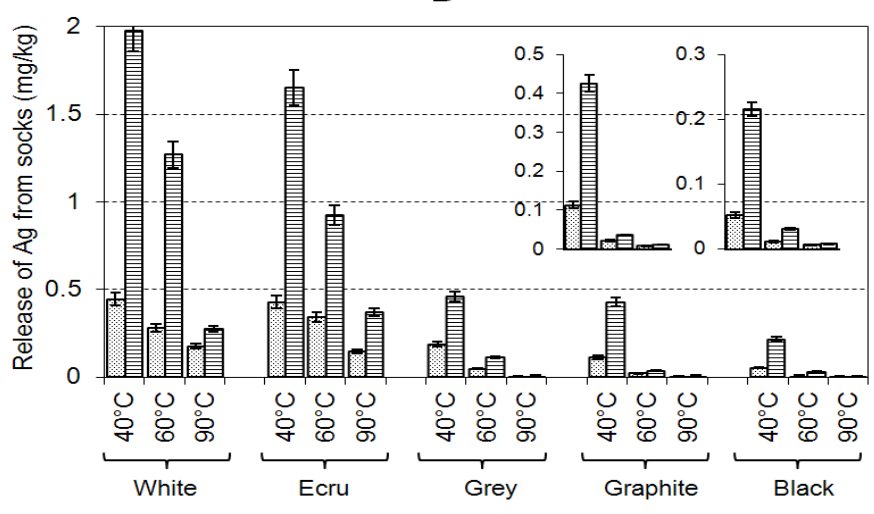

目 $1: 500$

Figure 6: Release of $\mathrm{Ag}$ from socks in $\mu \mathrm{g} / \mathrm{l}(\mathrm{A})$ and $\mathrm{mg} / \mathrm{kg}(\mathrm{B})$ at sock mass: water volume ratio of 1:100 and 1:500.

A

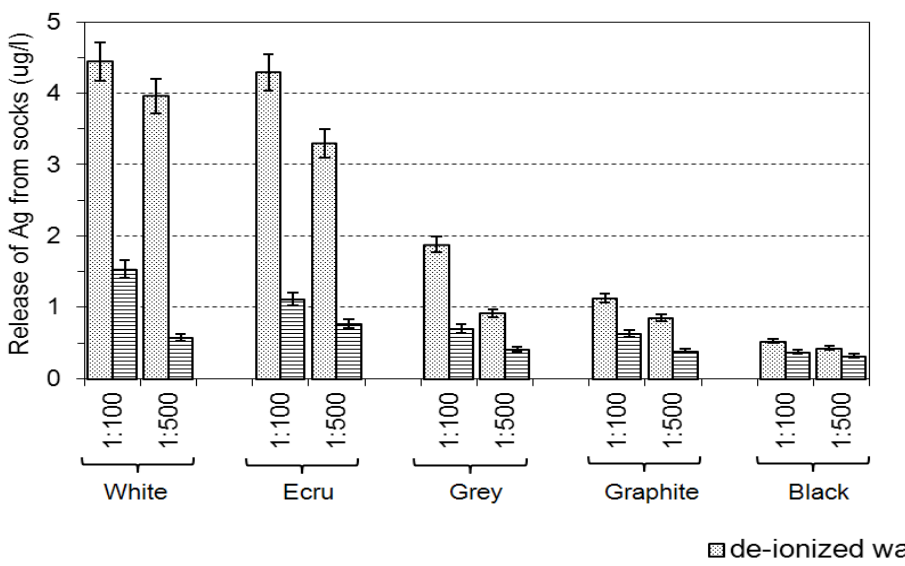

B

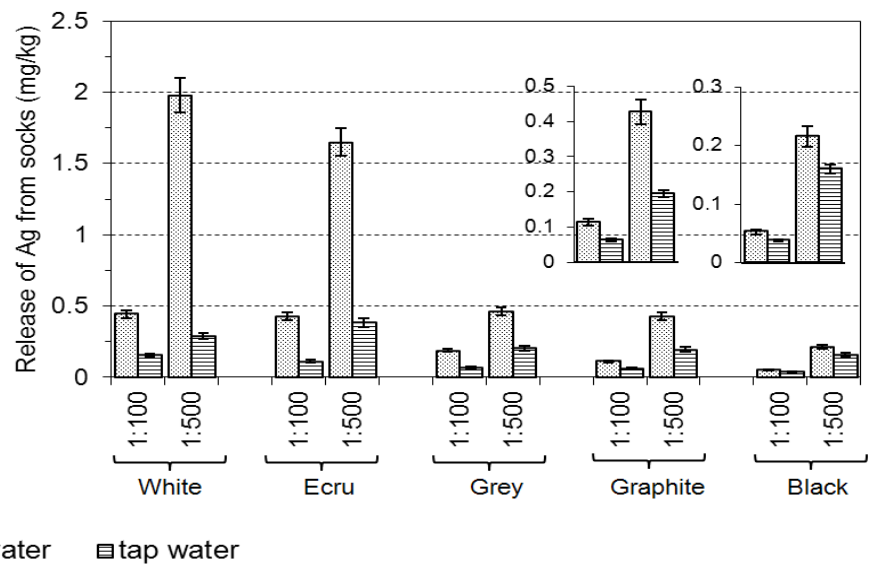

Figure 7: Effect of water chemical composition on the Ag release from socks ( $\mu \mathrm{g} / \mathrm{l}(A)$ and $\mathrm{mg} / \mathrm{kg}(B))$.

very low and the solubility constant $K_{s p}$ for $\mathrm{AgCl}$ is equal to $1.77 \times 10^{-10}$ $\mathrm{mol}^{2} / \mathrm{l}^{2}$ at $25^{\circ} \mathrm{C}$. Thus, the solubility is $1.33 \times 10^{-5} \mathrm{~mol} / \mathrm{l}$. An additional source of the common ion chloride present in the solution may lead to the $\mathrm{AgCl}$ solubility decrease (common-ion effect). The high $\mathrm{pH}$ of the washing solutions (8.15 to 7.67) and high concentration of ligands in tap water can cause the Ag complexation and precipitation [40]. The results of the study conducted by Impellitteri et al. [25] suggested that during the washing metallic $\mathrm{Ag}$ is oxidized and transformed into $\mathrm{AgCl}$. The discussed laboratory experiment consisted in the chloride acid solution addition to the AgNP solution and to the $\mathrm{Ag}^{+}$solution with the same concentrations and volumes. The experiment showed that a lower volume of the acid solution was needed for the $\mathrm{AgCl}$ precipitation from the $\mathrm{Ag}^{+}$solution than from the AgNP solution.

The Ag sensitivity strongly depends on the $\mathrm{Cl}^{-}$ion concentration. Moderate $\mathrm{Cl}^{-}$levels interact with Ag (nanoparticle and ionic forms) and precipitate as $\mathrm{AgCl}$. Consequently, the available $\mathrm{Ag}$ level decreases. However, higher amount of $\mathrm{Cl}^{-}$results in the repeated $\mathrm{Ag}$ dissolution [41]. The tap water contains sulphate ions $(64 \mathrm{mg} / \mathrm{l})$. Due to the $\mathrm{Ag}_{2} \mathrm{SO}_{4}$ solubility $\left(0.015326 \mathrm{~mol} / \mathrm{dm}^{3}\right)$, this phase is unlikely to have formed. Mitrano et al. [40] proposed a mechanism consisting in the sulphur reduction and subsequent formation of the $\mathrm{Ag}-\mathrm{S}$ particles. The presented washing experiment was conducted under oxidation conditions (pH 7.67-8.15 and Eh $220-230 \mathrm{mV}$ ). The S species analysis based on the in Eh-pH diagrams [42] indicated the unlikeliness of the sulphide phase formation under such conditions. The study of Lombi et al. [43] demonstrated that the Ag species in the commercial textiles varied between different textiles $(\mathrm{Ag}(\mathrm{O}), \mathrm{AgCl}, \mathrm{AgS}, \mathrm{Ag}$-phosphate and ionic Ag). They also demonstrated various release abilities. The chemical analysis of tap water demonstrated the presence of $\mathrm{HCO}_{3}{ }^{2}$ anion and $\mathrm{Ca}^{2+}$ and $\mathrm{Mg}^{2+}$ cations $(280.68 \mathrm{mg} / \mathrm{l}, 89 \mathrm{mg} / \mathrm{l}$ and $27 \mathrm{mg} / \mathrm{l}$, respectively). At high temperature, $\mathrm{CaCO}_{3}$ is precipitated (according to the reaction: $\mathrm{Ca}^{2+}+2 \mathrm{HCO}_{3}^{-}+\mathrm{H}_{2} \mathrm{O}+\mathrm{CO}_{2}$ ), which contributes to the precipitation/co-precipitation of $\mathrm{Ag}_{2} \mathrm{CO}_{3}$ due to the very low its solubility constant $\left(K_{s p}=8.46 \times 10^{-12} \mathrm{~mol}^{2} / \mathrm{l}^{2}\right)$. The Ag concentration decrease in the tap water during washing was a complex process, which depended on the chemical composition of water.

\section{Bleaching agent presence effect}

The bleaching agent impact (concentration of 1\%; $5 \mathrm{ml}$ in $500 \mathrm{ml}$ of water) on the Ag release was investigated for all the socks at textile mass: DI water ratio of 1:500 (Figure 8). For all the studied textiles, a significant release of $\mathrm{Ag}$ in the solution was observed after the bleaching agent was added because hydrogen peroxide decomposes into water and oxygen (equation 2). The oxidising effect depended on 
the washing process temperature and sock colour. It was found out that the released $\mathrm{Ag}$ contents increased when the temperature rose. The maximum Ag concentration $(12.9 \mu \mathrm{g} / \mathrm{l})$ was found in the ecru sock washing solution at $90^{\circ} \mathrm{C}$. At $40^{\circ} \mathrm{C}$, the released $\mathrm{Ag}$ concentration and loads in the solution in the oxidising agent presence were higher by $1.24-1.88$ times for all the socks than in the situation when the oxidising agent was absent. At $90^{\circ} \mathrm{C}$, the released $\mathrm{Ag}$ content was 23.29 and 17.38 times higher for the white and ecru socks and 100171 times higher for the colourful socks (Figure 8). At the same time, the TOC content in the white sock washing solution in the presence of a bleaching agent at 40,60 and $90^{\circ} \mathrm{C}$ was $230 \mathrm{mgC} / \mathrm{l}, 313.6 \mathrm{mgC} / \mathrm{l}$ and $356 \mathrm{mgC} / \mathrm{l}$, respectively. When the bleaching agent was not used, the TOC contents in the washing solution were 5.67-6.79 $\mathrm{mgC} / \mathrm{l}$. The results demonstrate that the oxidising properties of the bleaching agent improved with the increasing temperature. Oxygen released from $\mathrm{H}_{2} \mathrm{O}_{2}$ (equation 2) and may have also oxidised the cotton fibres in the socks and dyes incorporated in the fibres. Consequently, the Ag bound to the cotton fibres and dyes may have also been oxidised. Consequently, the Ag was higher released from colourful textiles. The enhancement in the hydrogen peroxide decomposition at high temperature was due to the favourable temperature effect in the increasing kinetic energy of the bleaching species and in the increasing swelling of cotton fibres. This resulted in higher accessibility. Therefore, the oxidizing species could easily penetrate the bulk of the fibre and remove the noncellulose matter and dyes [44]. The AgNP oxidation with $\mathrm{H}_{2} \mathrm{O}_{2}$ was thermodynamically feasible with the standard redox potential.

Despite the total Ag concentration increase in the solution, in the oxidising agent presence, the $\mathrm{Ag}^{+}$ion concentration in the solution was undetectable with the potentiometric method. In order to define the influence of the oxidising agent presence on the Ag species in the solution, an experiment was conducted. It consisted in determining the total $\mathrm{Ag}$ and $\mathrm{Ag}^{+}$concentrations in the solutions with $\mathrm{AgNPs}$ (concentrations of 1,10 and $50 \mathrm{mg} / \mathrm{l}$ ) without or in the presence of the oxidising agent (concentration of 1\%) (Table 3). The solutions were kept at 40,60 and $90^{\circ} \mathrm{C}$ in the water bath for 1 hour. Afterwards, the $\mathrm{Ag}$ and $\mathrm{Ag}^{+}$concentrations were determined with $\mathrm{AAS}$ and potentiometric methods, respectively. The results are shown in Table 4 . They indicate that the $\mathrm{Ag}^{+}$ion concentration increased with the solution temperature and oxidant concentration. In the presence of the bleaching agent and at 60 and $90^{\circ} \mathrm{C}$, precipitation of a grey-black solid phase and decrease in the total Ag concentration in the solution with $50 \mathrm{mg} / \mathrm{l}$ were observed for the AgNP concentration of $50 \mathrm{mg} / \mathrm{l}$. The precipitate was soluble in both the ammonia solution and concentrated nitric acid. It yielded a brownish solution containing the $\mathrm{Ag}^{+}$ions, which indicated that the precipitate was $\mathrm{Ag}_{2} \mathrm{O}$.

Glover et al. [45] observed that in the vicinity of the parent $\mathrm{Ag}$ particles, smaller $\mathrm{Ag}$ nanoparticles are formed via the oxidation to $\mathrm{Ag}^{+}$ ions and the subsequent reduction to the daughter Ag nanoparticle forms. The studies of Benn et al. [23], Farkas et al. [24] and Impellitteri et al. [25] showed that during washing of textiles filled with AgNPs, Ag is released. However, the chemical species of the released Ag remains unclear in most studies.

\begin{tabular}{|c|c|c|c|c|c|c|}
\hline \multirow{2}{*}{$\begin{array}{l}\text { Temperature } \\
\left({ }^{\circ} \mathrm{C}\right)\end{array}$} & $\mathbf{A g}^{+}$ & $\mathbf{A g}_{\mathrm{t}}$ & $\% \mathrm{Ag}^{+}$ & $\mathrm{Ag}^{+}$ & $\mathbf{A g}_{\mathrm{t}}$ & $\% \mathrm{Ag}^{+}$ \\
\hline & \multicolumn{3}{|c|}{$1 \mathrm{mg} / \mathrm{l}$ AgNPs } & \multicolumn{3}{|c|}{$1 \mathrm{mg} / \mathrm{l}$ AgNPs $+1 \%$ oxidant } \\
\hline $40^{\circ} \mathrm{C}$ & 0.08 & 0.99 & 8.08 & 0.98 & 1.05 & 93.33 \\
\hline $60^{\circ} \mathrm{C}$ & 0.47 & 0.99 & 47.48 & 1.05 & 1.05 & 100 \\
\hline \multirow[t]{2}{*}{$90^{\circ} \mathrm{C}$} & 0.65 & 0.98 & 66.33 & 1.05 & 1.05 & 100 \\
\hline & \multicolumn{3}{|c|}{$10 \mathrm{mg} / \mathrm{l}$ AgNPs } & \multicolumn{3}{|c|}{10 mg/l AgNPs $+1 \%$ oxidant } \\
\hline $40^{\circ} \mathrm{C}$ & 0.85 & 10.1 & 8.41 & 9.6 & 10.0 & 96.00 \\
\hline $60^{\circ} \mathrm{C}$ & 2.03 & 10.0 & 20.3 & 9.8 & 10.0 & 98.00 \\
\hline \multirow[t]{2}{*}{$90^{\circ} \mathrm{C}$} & 3.15 & 10.0 & 31.5 & 9.9 & 10.0 & 99.00 \\
\hline & \multicolumn{3}{|c|}{$50 \mathrm{mg} / \mathrm{l}$ AgNPs } & \multicolumn{3}{|c|}{$50 \mathrm{mg} / \mathrm{l}$ AgNPs $+1 \%$ oxidant } \\
\hline $40^{\circ} \mathrm{C}$ & 1.96 & 49.5 & 3.96 & 32.7 & 49.5 & 66.06 \\
\hline $60^{\circ} \mathrm{C}$ & 2.86 & 49.5 & 5.78 & 35.4 & 35.5 & 99.70 \\
\hline $90^{\circ} \mathrm{C}$ & 3.66 & 49.5 & 7.40 & 32.0 & 32.0 & 100 \\
\hline
\end{tabular}

Table 3: $\mathrm{Ag}^{+}$and $\mathrm{Ag}_{\mathrm{t}}$ concentrations in the AgNP solution after heating (mg/l).

\begin{tabular}{|c|c|c|c|c|c|c|c|}
\hline $\begin{array}{c}\text { Cotton } \\
\text { samples } \\
\mathbf{C} \text { /time/T }\end{array}$ & $\begin{array}{c}\mathbf{A g}_{\mathbf{t}} \\
\mathbf{( \mu g / l )}\end{array}$ & $\begin{array}{c}\mathbf{A g}^{+} \\
\mathbf{( \mu g / l )}\end{array}$ & $\begin{array}{c}\text { \% of } \\
\text { ionic } \\
\text { form }\end{array}$ & $\begin{array}{c}\text { Cotton } \\
\text { samples } \\
\mathbf{C}_{\mathbf{o}} \text { /time/T }\end{array}$ & $\begin{array}{c}\mathbf{A g}_{\mathbf{t}} \\
\mathbf{( \mu g / l )}\end{array}$ & $\begin{array}{c}\mathbf{A g}^{+} \\
\mathbf{( \mu g / l )}\end{array}$ & $\begin{array}{c}\text { \% of } \\
\text { ionic } \\
\text { form }\end{array}$ \\
\hline $25 / 15 / 25^{\circ} \mathrm{C}$ & 27.74 & 11.5 & 41.45 & $25 / 60 / 25^{\circ} \mathrm{C}$ & 39.42 & 22.1 & 56.06 \\
\hline $25 / 15 / 40^{\circ} \mathrm{C}$ & 38.58 & 21.4 & 55.47 & $25 / 60 / 40^{\circ} \mathrm{C}$ & 48.00 & 28.5 & 59.37 \\
\hline $25 / 15 / 60^{\circ} \mathrm{C}$ & 67.03 & 41.8 & 62.36 & $25 / 60 / 60^{\circ} \mathrm{C}$ & 70.01 & 30.5 & 78.18 \\
\hline $25 / 15 / 90^{\circ} \mathrm{C}$ & 57.97 & 52.3 & 90.22 & $25 / 60 / 90^{\circ} \mathrm{C}$ & 64.95 & 59.2 & 91.15 \\
\hline $50 / 15 / 25^{\circ} \mathrm{C}$ & 59.25 & 23.3 & 39.32 & $50 / 60 / 25^{\circ} \mathrm{C}$ & 65.39 & 33.1 & 50.62 \\
\hline $50 / 15 / 40^{\circ} \mathrm{C}$ & 74.52 & 40.1 & 53.81 & $50 / 60 / 40^{\circ} \mathrm{C}$ & 81.29 & 45.3 & 55.73 \\
\hline $50 / 15 / 60^{\circ} \mathrm{C}$ & 99.11 & 59.4 & 59.93 & $50 / 60 / 60^{\circ} \mathrm{C}$ & 103.0 & 64.3 & 62.42 \\
\hline $50 / 15 / 90^{\circ} \mathrm{C}$ & 68.99 & 61.9 & 89.72 & $50 / 60 / 90^{\circ} \mathrm{C}$ & 81.85 & 71.8 & 87.72 \\
\hline
\end{tabular}

Table 4: Ag species in the solution after the washing process of cotton filled with AgNPs.
A

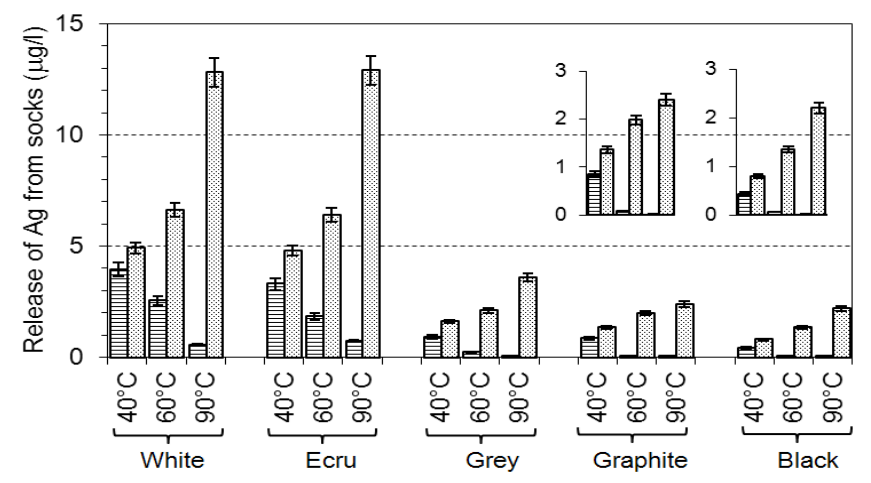

B

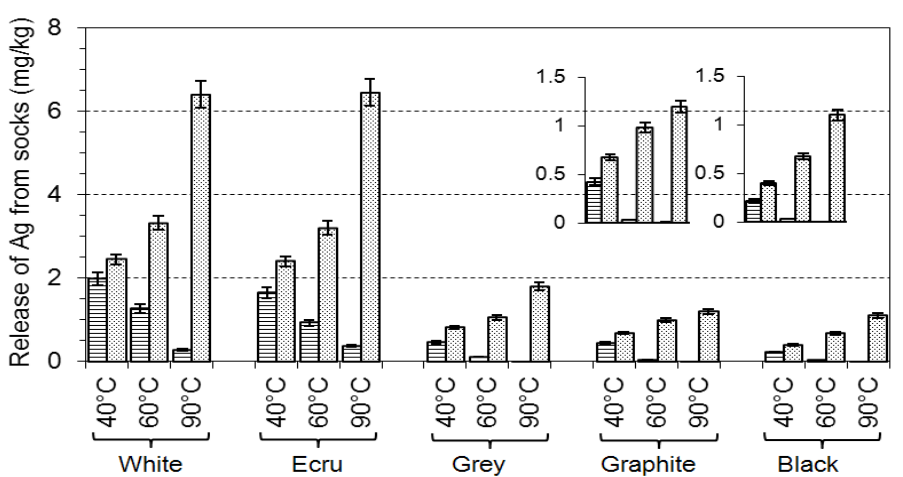

目Without bleaching agent With bleaching agent

Figure 8: Bleaching agent effect on the Ag release from socks $(\mu \mathrm{g} / \mathrm{l}(\mathrm{A})$ and $\mathrm{mg} / \mathrm{kg}(\mathrm{B}))$. 


\section{Ag release from cotton and viscose - effect of textile type}

The Ag release from textiles filled with AgNPs during the washing process with DI water depended strongly on the textile structure. The released Ag concentration and load from cotton filled with AgNPs was higher than from viscose prepared under the same conditions. The amount of Ag removed from the cotton fibres to the solution depended on the washing temperature and total $\mathrm{Ag}$ content in the washed textiles. At the low AgNPs content (initial Ag concentration in the impregnation solution: $1 \mathrm{mg} / \mathrm{l}$ ) in cotton, the released $\mathrm{Ag}$ concentration and load increased with temperature from 0.61 to $1.21 \mu \mathrm{g} / \mathrm{l}$ and 0.312 $\mathrm{mg} / \mathrm{kg}$ to $0.6051 \mathrm{mg} / \mathrm{kg}$, respectively (contact time $=15 \mathrm{~min}$ ) and from 0.64 to $9.499 \mu \mathrm{g} / \mathrm{l}$ and $0.3199 \mathrm{mg} / \mathrm{kg}$ to $1.324 \mathrm{mg} / \mathrm{kg}$ (contact time $=60$ $\mathrm{min}$ ). The highest $\mathrm{Ag}$ amount was released at $90^{\circ} \mathrm{C}$ (Figures 9A and 9B). When higher Ag concentrations were used for impregnating cotton, the highest Ag concentration and load were released at $60^{\circ} \mathrm{C}$. The effect of the initial filling AgNP concentration $\left(\mathrm{C}_{\mathrm{o}}\right)$ of on the Ag amount released into the solution was as follows:

1. For $\mathrm{C}_{0} 5 \mathrm{mg} / \mathrm{l}: \mathrm{Ag}$ was released into the solution in the range of $5.37-8.06 \mu \mathrm{g} / \mathrm{l}(2.683 \mathrm{mg} / \mathrm{kg}-4.028 \mathrm{mg} / \mathrm{kg})$ for contact time of 15 $\mathrm{min}$, and $8.29-17.47 \mu \mathrm{g} / \mathrm{l}(4.146-8.734 \mathrm{mg} / \mathrm{kg})$ for contact time of $60 \mathrm{~min}$;

2. For $\mathrm{C}_{\mathrm{o}} 25 \mathrm{mg} / \mathrm{l}: \mathrm{Ag}$ was released into the solution in the range of $27.74-67.03 \mu \mathrm{g} / \mathrm{l}(13.858-33.48 \mathrm{mg} / \mathrm{kg})$ for contact time of $15 \mathrm{~min}$, and $39.42-70.01 \mu \mathrm{g} / \mathrm{l}(19.71$ to $35.03 \mathrm{mg} / \mathrm{kg}$ ) for contact time of 60 min;

3. For C $50 \mathrm{mg} / \mathrm{l}: \mathrm{Ag}$ was released into the solution in the range of $59.25-99.11 \mu \mathrm{g} / \mathrm{l}(29.60-49.54 \mathrm{mg} / \mathrm{kg})$ for contact time of $15 \mathrm{~min}$, and $65.39-103.01 \mu \mathrm{g} / \mathrm{l}(32.72-51.52 \mathrm{mg} / \mathrm{kg})$ for contact time of 60 $\min$.

The Ag percentage removal from cotton ranged from 6.57 to $33.77 \%$ at $15-\mathrm{min}$ contact time and from 6.56 to $32.94 \%$ at $60-\mathrm{min}$ contact time. The $\mathrm{pH}$ values were $6.08-7.60$ and the $\mathrm{pH}$ increase with temperature was observed.

The Ag removal from viscose filled with AgNPs was considerably lower. Moreover, the highest released Ag loads were observed at $90^{\circ} \mathrm{C}$ regardless of the initial Ag concentration in the solutions used for the textile impregnation (saturation). The effect of the initial concentration on the Ag release into the solution was lower than for cotton. The $\mathrm{Ag}$ concentration in the solution after washing was $0.060-16.51 \mu \mathrm{g} / \mathrm{l}$ for textiles impregnated for $15 \mathrm{~min}$ and $0.120-20.95 \mu \mathrm{g} / \mathrm{l}$ for textiles impregnated for $60 \mathrm{~min}$. The released Ag load was $0.0322-8.246 \mathrm{mg} /$ $\mathrm{kg}$ and $0.0599-10.459 \mathrm{mg} / \mathrm{kg}$, respectively. The Ag percentage removal ranged from 0.36 to $3.566 \%$ and from 0.6087 to $4.12 \%$, respectively. The washing process for viscose occurred at lower $\mathrm{pH}$ than for cotton. It ranged from 4.41 to 6.11 . Similarly to cotton, the $\mathrm{pH}$ increase with temperature was observed.

The results indicate that the textile structure (particularly the content of surface functional groups) affected the amount of $\mathrm{Ag}$ impregnating the textile and Ag binding strength on the fibre surfaces. It also played an important role in the Ag release into water. After the washing of AgNPs-filled cotton ( $\mathrm{C}_{\mathrm{o}}: 25 \mathrm{mg} / \mathrm{l}$ and $50 \mathrm{mg} / \mathrm{l}$ ) at different temperatures, the $\mathrm{Ag}^{+}$ion concentration in the solution was determined with the potentiometric method with ion-selective electrodes (ISEs). The value was compared with the total released Ag amount determined with AAS. The result indicated that the $\mathrm{Ag}^{+}$ion concentration in the solution was dependent on the temperature. Its lowest value was observed at $25^{\circ} \mathrm{C}$ and increased with the rising temperature (Table 4).
The percentage of $\mathrm{Ag}^{+}$released from the cotton samples changed from $42.87-56.90 \%$ at $25^{\circ} \mathrm{C}$ to $15.57-18.69 \%$ at $90^{\circ} \mathrm{C}$.

When the elemental Ag nanoparticles are in contact with water and dissolved oxygen coming from air, the Ag ions are released from the surface of textile filled with AgNPs in accordance with the equation:

$$
\mathrm{O}_{2(\mathrm{aq})}+4 \mathrm{H}^{+}+4 \mathrm{Ag} \rightarrow 4 \mathrm{Ag}_{(\text {aq) }}^{+}+2 \mathrm{H}_{2} \mathrm{O}
$$

The effects of $\mathrm{O}_{2}$ can be explained with the fact that the electron transfer from the Ag particles to the solute occurred [39,46].

Liu and Hurt [39] reveal that for a water solution under airsaturated conditions, the nano-Ag particle oxidation is observed in the entire range of the investigated nanoparticle concentration, whereas the Ag ion release from the nanoparticle surfaces increases with the rising temperature. The results obtained in this experiment show a similar distribution of $\mathrm{Ag}^{+}$ion in the function of temperature.

For textiles containing metallic $\mathrm{Ag}$, the $\mathrm{Ag}(\mathrm{O})$ oxidation to $\mathrm{Ag}(\mathrm{I})$ in contact with water is a prerequisite for the appearance of the $\mathrm{Ag}^{+}$ions in the solution [22].

The AgNP oxidation process with dissolvent oxygen depended on the AgNPs size. The smaller the nanoparticles are, the larger the surface available for the interaction is, which results in a higher specific activity. Compared to larger AgNPs, small AgNPs release more $\mathrm{Ag}^{+}$ ions [41,47]. Smaller AgNPs (5 nm) dissolved more rapidly than larger AgNPs $(50 \mathrm{~nm})$ in aqueous systems, which could be due to larger fraction of the surface atoms (higher specific surface area) in smaller AgNPs or due to lower redox potentials of smaller AgNPs [48]. The size of AgNPs used in the discussed experiments ranged from $8 \mathrm{~nm}$ to 18 $\mathrm{nm}$, which suggests that AgNPs could be easily oxidised and dissolved easily (Table 4)

The research carried out by Silva et al. [49] showed that the pseudofirst-order equation fitted well with the data on the $\mathrm{Ag}^{+}$ion release from the plant cellulose fibres $(\mu \mathrm{m})$ filled with AgNPs. This suggests that the Ag oxidation is a stage limiting the Ag release process.

\section{Eco-toxicity test}

The toxicity of a water solution containing Ag is presented in Table 1. D. magna showed higher sensitivity to Ag than $V$. fischeri. The EC50 values for $D$. magna were 46 times lower than for $V$. fischeri. The lowest EC50 value was determined for samples $C$ (Cotton $\left.50 / 60 / 60^{\circ} \mathrm{C}\right)$. The highest EC50 value was determined for samples A (D. magna) and B ( $V$. fischeri) (Table 5). According to the TU values obtained for $D$. magna, all the studied samples should be classified as class IV toxic compounds (high acute hazard) and for $V$. fischeri as class III toxic compounds (acute hazard). Different research studies [28,30] showed that the lowest EC50 value $<1 \mathrm{mg} / \mathrm{l}$ classifies chemicals as very toxic to aquatic organisms; $1-10 \mathrm{mg} / \mathrm{l}=$ toxic to aquatic organisms; $10-100 \mathrm{mg} /$ $\mathrm{l}=$ harmful to aquatic organisms; $>100 \mathrm{mg} / \mathrm{l}=$ not classified. In the research carried out for this study, the water extracts with Ag were very toxic (D. magna) and toxic (V. fischeri) for aquatic organisms. The release of the discussed nanoparticles from household products into wastewater streams and further into the environment may pose a threat to the 'non-target' organisms, such as microbes and aquatic organism [50]. It is also well known that AgNPs are most toxic to the aquatic organisms [51,52]. Different authors discovered several mechanisms to explain the toxic effect of Ag nanoparticles: 1) the presence of the AgNPs themselves; 2) the release of $\mathrm{Ag}^{+}$from nanoparticles; 3) free radicals generated during dissolution in the AgNP suspension [53,54] reported that the toxicity of AgNPs was caused by the Ag ions emitted from the nano-material surface. Consequently, the toxicity mechanisms 
A

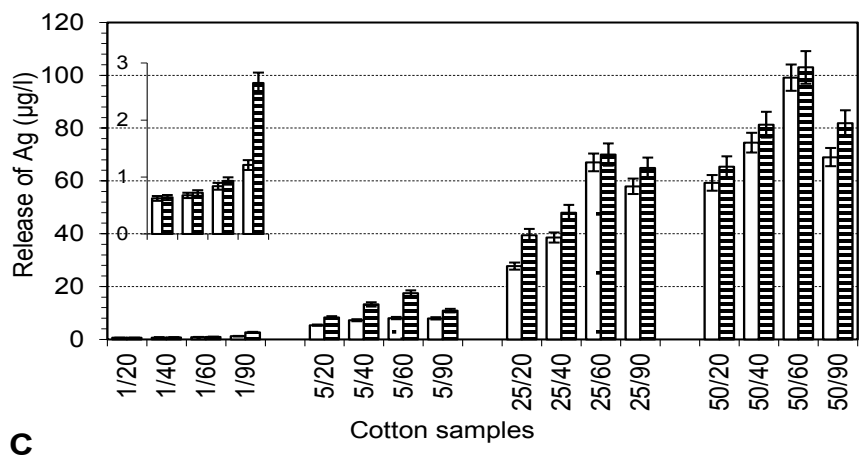

C

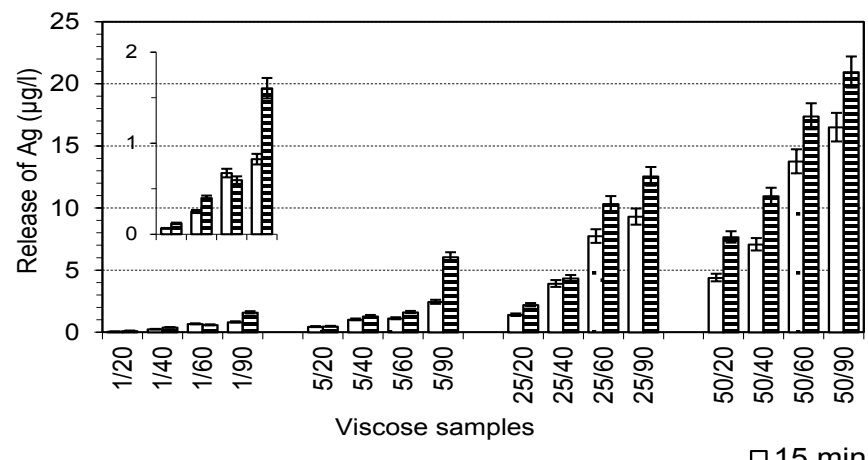

B
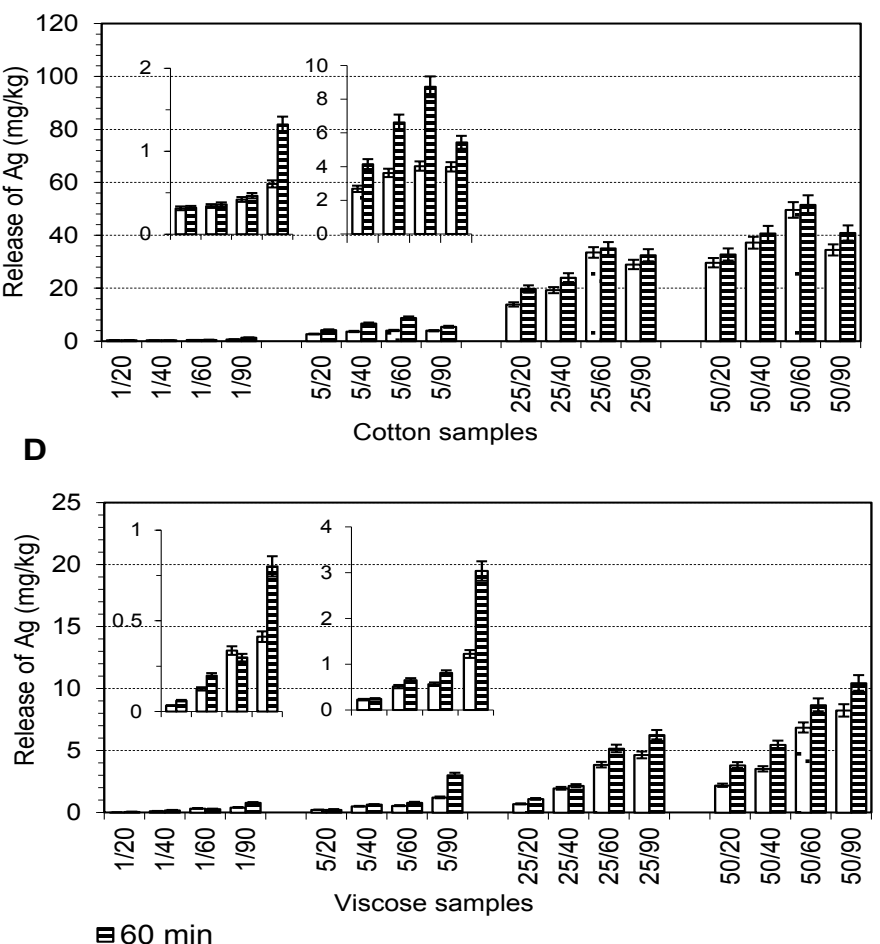

Figure 9: Ag release from cotton and viscose in $\mu \mathrm{g} / \mathrm{l}(\mathrm{A}$ and $\mathrm{C})$ and $\mathrm{mg} / \mathrm{kg}(\mathrm{B}$ and $\mathrm{D})$ at mass of textile to water-volume ratio of 1:500, contact time of impregnation $15 \mathrm{~min}$ and $60 \mathrm{~min}$.

\begin{tabular}{|c|c|c|c|c|}
\hline \multirow{2}{*}{ Samples } & \multicolumn{2}{|c|}{ D. magna } & \multicolumn{2}{c|}{ V. fischeri } \\
\cline { 2 - 5 } & EC50 $\mathbf{~ m g / l}$ & TU & EC50 mg/l & TU \\
\hline $\begin{array}{c}\text { A - Cotton } \\
50 / 60 / 90^{\circ} \mathrm{C}\end{array}$ & 0.033 & 30.53 & 1.380 & 7.25 \\
\hline $\begin{array}{c}\text { B - Cotton } \\
50 / 60 / 40^{\circ} \mathrm{C}\end{array}$ & 0.032 & 31.51 & 1.710 & 5.85 \\
\hline $\begin{array}{c}\mathrm{C}-\text { Cotton } \\
50 / 60 / 60^{\circ} \mathrm{C}\end{array}$ & 0.028 & 35.17 & 1.160 & 8.62 \\
\hline
\end{tabular}

Table 5: Toxicity of water solutions containing AgNPs toxicity for organisms.

observed for Ag nanoparticles and Ag ions seem similar. The present study results demonstrated that the Ag water solution samples revealed a toxic effect on D. magna and V. fischeri. Among the tested species, D. magna was most sensitive and revealed acute toxicity for low EC50 values. The low EC50 values obtained for D. magna were caused by their filter-feeding strategy leading to an effective nanoparticle uptake $[29,55]$ found out that D. magna could retain AgNPs in their internal organs after ingestion (Table 5). Moreover, D. magna is frequently used in the nano-ecotoxicological tests because it is one of the organisms most sensitive to toxic chemicals. It also occupies the central position in the food chain $[29,30,51,53,56]$. As Daphnia is an element of the diet of other aquatic organisms (e.g. fish), it is an important link in the potential uptake and transfer of nanoparticles to higher organisms [29]. For that reason, a relatively high number of results concerning this species is described and published. The study of Binaeian et al. [57] showed that $V$. fischeri was also sensitive to the toxicity effects of $\mathrm{Ag}$ ions and nanoparticles and could be used as a biosensor of the acute nanoparticle toxicity. It was found out that the $\mathrm{Ag}$ ions were more toxic for $V$. fischeri than the Ag nanoparticles [50,57] discovered that the AgNPs were less toxic to bacteria than to aquatic organisms. The studies are consistent with the results obtained in this study (Table 1).
The EC50 values for Ag nanoparticles were 0.01, 0.36, 1.36, and 7.1 $\mathrm{mg} / \mathrm{l}$ for crustaceans, algae, fish and bacteria, respectively [50]. The response of $V$. fischeri was less sensitive due to the physiological state of the bacteria. Small particles tend to show high toxicity to aquatic organisms. When the particle size is smaller than the cell wall pore $(5-20 \mathrm{~nm})$, they can easily penetrate the algal cell [58].

\section{Conclusion}

The study investigates the Ag release from textiles (socks available in the Polish market, cotton and viscose filled with Ag nanoparticles) into the washing solution under different conditions. The released $\mathrm{Ag}$ amount depended on a multitude of factors, such as test media (chemical composition, temperature and water volume), metal contents, or textile impregnation condition. Furthermore, the textile type and colour were the main parameters affecting the Ag release. The $\mathrm{Ag}$ concentration in the washing solution was $0.015-4.44 \mu \mathrm{g} / \mathrm{l}$ (socks) and $0.61-103 \mu \mathrm{g} / \mathrm{l}$ (cotton filled with AgNPs). The percentage of the total $\mathrm{Ag}$ released into water during one washing varied considerably among textiles (from less than 1 to $34 \%$ ). In the presence of tap water, the released Ag load decreased from 6.82 to $1.35 \mathrm{mg} / \mathrm{kg}$ due to the $\mathrm{AgCl}$ and/or $\mathrm{Ag}_{2} \mathrm{CO}_{3}$ precipitation.

The bleaching process had a strong effect on the quality and speciation of Ag released in the washing process. For example, the $\mathrm{Ag}$ concentration in the washing solution changed from $0.8 \mu \mathrm{g} / \mathrm{l}$ to $12.9 \mu \mathrm{g} / \mathrm{l}$ and was higher by 20 times (white socks) and up to 170 times (black socks) when compared to washing in water without any oxidising agent. The washing of the nano-Ag-treated textiles may have potentially released both ionic and particle Ag forms because smaller AgNPs dissolved more rapidly than larger AgNPs. The situation is due to the larger fraction of surface atoms (higher specific surface area) in 
smaller AgNPs or due to lower redox potentials of smaller AgNPs (in comparison with large particles). Furthermore, small particles tend to show high toxicity towards aquatic organisms. When the particle size is smaller than the cell wall pore $(5-20 \mathrm{~nm})$, they can easily penetrate the algal cell. The results of the present study demonstrated that the water solution containing Ag revealed a toxic effect on D. magna and $V$. fischeri. Among the tested species, D. magna was most sensitive and revealed acute toxicity for low EC50 values. The response of $V$. fischeri was less sensitive due to the physiological state of the bacteria. The information obtained in this study may be used to evaluate the potential risk to the ecological system posed by textiles from which AgNPs are released during their life cycle.

\section{Acknowledgement}

The authors would like to thank the National Science Centre (NCN) in Poland for supporting this work under the NCN UMO-2012/07/B/ST8/03753 project in 2013-2016. The authors would also like to express their gratitude to Iwona Krzyżewska and Magdalena Jabłońska-Czapla, D.Sc. for the analytical work conducted in this study.

\section{References}

1. ISO/TS 27687 (2008) Nanotechnologies (1stedn) - Terminology and definitions for nano-objects - nanoparticle, nanofibre and nanoplate.

2. Ma X, Geiser-Lee J, Deng $Y$, Kolmakov A (2010) Interactions between engineered nanoparticles (ENPs) and plants: phytotoxicity, uptake and accumulation. Sci Total Environ 408: 3053-3061.

3. Höfer D (2006) Antimicrobial textiles - evaluation of their effectiveness and safety. Curr Probl Dermatol 33: 42-50.

4. Fabrega J, Luoma SN, Tyler CR, Galloway TS, Lead JR (2011) Silver nanoparticles: Behaviour and effects in the aquatic environment. Environ Int 37: 517-531.

5. http: //www.nanotechproject.org

6. Jeong SH, Yeo SY, Yi SC (2005) The effect of filler particle size on the antibacterial properties of compounded polymer/silver fibers. J Mater Sci 40: 5407-5411.

7. Tugulea AM, Bérubé D, Giddings M, Lemieux F, Hnatiw J, et al. (2014) Nanosilver in drinking water and drinking water sources: stability and influences on disinfection by-product formation. Environ Sci Pollut R 21: 11823-11831.

8. Benn TM, Westerhoff P (2008) Nanoparticle silver released into water from commercially available sock fabrics. Environ Sci Technol 42: 4133-4139.

9. Bystrzejewska-Piotrowska G, Golimowski J, Urban PL (2009) Nanoparticles: their potential toxicity, waste and environmental management. Waste Manage 29: 2587-2595.

10. Wijnhoven SWP, Peijnenburg WJGM, Herberts CA, Hagens WI, Oomen AG et al. (2009) Nano-silver - a review of available data and knowledge gaps in human and environmental risk assessment. Nanotoxicology 3: 109-138.

11. Kim B, Park CS, Murayama M, Hochella MF (2010) Discovery and characterization of silver sulfide nanoparticles in final sewage sludge products. Environ Sci Technol 44: 7509-7514.

12. Dastjerdi R, Montazer M, Shahsavan S (2009) A new method to stabilize nanoparticles on textile surfaces. Colloid Surface A 345: 202-210.

13. Dastjerdi R, Mojtahedi MRM, Shoshtari AM, Khosroshahi A (2010) Investigating the production and properties of $\mathrm{Ag} / \mathrm{TiO} 2 / \mathrm{PP}$ antibacterial nanocomposite filament yarns. J Text I 101: 204-213.

14. Sakamoto M, Kataoka C, Kashiwada S, Ha JY, Tatsuta H, et al. (2015) Free silver ion as the main cause of acute and chronic toxicity of silver nanoparticles to cladocerans. Arch Environ Con Tox 68: 500-509.

15. Gottschalk F, Sonderer T, Scholz RW, Nowack B (2009) Modeled environmenta concentrations of engineered nanomaterials $\left(\mathrm{TiO}_{2}, \mathrm{ZnO}, \mathrm{Ag}, \mathrm{CNT}\right.$, fullerenes) for different regions. Environ Sci Technol 43: 9216-9222.

16. WHO (World Health Organization) (2011) Guidelines for drinking-water quality (4thedn).

17. Drake PL, Hazelwood KJ (2005) Exposure-related health effects of silver and silver compounds: A Review. Ann Occup Hyg 49: 575-588.
8. Prabhu S, Poulose EK (2012) Silver nanoparticles: mechanism of antimicrobia action, synthesis, medical applications, and toxicity effects. Int Nano Lett 32 $1-10$.

19. Abou El-Nour KMM, Eftaiha A, Al-Warthan A, Ammar RAA (2010) Synthesis and applications of silver nanoparticles. Arab J Chem 3: 135-140.

20. Budama L, Çakir BA, Topel Ö, Hoda N (2013) A new strategy for producing antibacterial textile surfaces using silver nanoparticles. Chem Eng J 228: 489-495.

21. Wie D, Sun W, Qian W, Ye Y, Ma X (2009) The synthesis of chitosan-based silver nanoparticles and their antibacterial activity. Carbohyd Res 344: 23752382.

22. Geranio L, Heuberger M, Nowack B (2009) The behavior of silver nanotextiles during washing. Environ Sci Technol 43: 8113-8118.

23. Benn T, Cavanagh B, Hristovski K, Posner JD, Westerhoff $P$ (2010) The release of nanosilver from consumer products used in the home. $\mathrm{J}$ Environ Qual 39: 1875-1882.

24. Farkas J, Peter H, Christian P, Gallego Urrea JA, Hassellöv M, et al. (2011) Characterization of the effluent from a nanosilver producing washing machine. Environ Int 37: 1057-1062.

25. Impellitteri CA, Tolaymat TM, Scheckel K.G (2009) The speciation of silve nanoparticles in antimicrobial fabric before and after exposure to a hypochlorite/ detergent solution. J Environ Qual 38: 1528-1530.

26. Manusadžianas L, Balkelyt L, Sadauskas K, Blinova I, Põllumaa L, et al. (2003) Ecotoxicological study of Lithuanian and Estonian wastewaters: selection of the biotests, and correspondence between toxicity and chemical-based indices. Aquat Toxicol 63: 27-41

27. Pessala P, Schultz E, Nakari T, Joutti A, Herve S (2004) Evaluation of wastewater effluents by small-scale biotests and a fractionation procedure. Ecotox Environ Safe 59: 263-272.

28. Kalbassi MR, Salari-joo H, Johari A (2011) Toxicity of silver nanoparticles in aquatic ecosystems: Salinity as the main cause in reducing toxicity. Iran J Toxicol 5: 436-443.

29. Asghari S, Johari S, Lee J, Kim Y, Jeon Y, et al. (2012) Toxicity of various silver nanoparticles compared to silver ions in Daphnia magna. J Nanobiotechnol 10: 1-11.

30. Czech B, Jaśko I, Oleszczuk P (2014) Ecotoxicological evaluation of selected pharmaceuticals to Vibrio fischeri and Daphnia magna before and after photooxidation process. Ecotox Environ Safe 104: 247-253.

31. Crustacean toxicity screening test for freshwater (1996) Standard operationa procedure. Daphtoxkit FTM magna Creasel, Deinze, Belgium.

32. Microbics Corporation (1992) A Microtox manual. A toxicity testing handbook Carlsbad, California.

33. Persoone G, Marsalek B, Blinova I, Törökne A, Zarina D, et al. (2003) A practical and user-friendly toxicity classification system with microbiotests for natural waters and wastewaters. Environ Toxicol 18: 395-402.

34. Lorenz C, Windler L, von Goetz N, Lehmann RP, Schuppler M, et al. (2012) Characterization of silver release from commercially available functional (nano) textiles. Chemosphere 89: 817-824.

35. Kulthong K, Srisung S, Boonpavanitchakul K, Kangwansupamonkon W Maniratanachote $R$ (2010) Determination of silver nanoparticle release from antibacterial fabrics into artificial sweat. Part Fibre Toxicol 7: 1-9.

36. Ravindra S, Murali Mohan Y, Narayana Reddy N, Mohana Raju K (2010) Fabrication of antibacterial cotton fibres loaded with silver nanoparticles via "Green Approach". Colloids and surfaces A 367: 31-40.

37. Lim SH, Hudson SM (2004) Application of a fibre-reactive chitosan derivative to cotton fabric as an antimicrobial textile finish. Carbohyd Polym 56: 227-234.

38. Stepanik TM, Ewing DE, Whitehouse R (2000) Electron treatment of wood pulp for the viscose process. Radiat Phys Chem 57: 377-379.

39. Liu J, Hurt RH (2010) Ion release kinetics and particle persistence in aqueous nano-silver colloids. Environ Sci Technol 44: 2169-2175.

40. Mitrano DM, Rimmele E, Wichser A, Erni R, Height M, et al. (2014) Presence of nanoparticles in wash water from conventional silver and nano-silver textiles. ACS Nano 8: 7208-7219.

41. Mijnendonckx K, Mahillon J, Leys N, Silver S, van Houdt R (2013) Antimicrobia silver: uses, toxicity and potential for resistance. Biometals 26: 609-621. 
Citation: Kyzioł-Komosińska J, Baran A, Rosik-Dulewska C, Czupiol J, Boncel S, et al. (2016) Impact of Different Washing Conditions on the Release of Ag Species from Textiles. J Civil Environ Eng 6: 234. doi:10.4172/2165-784X.1000234

42. Takeno N (2005) Atlas of Eh-pH diagrams. Intercomparison of thermodynamic databases. Geological Survey of Japan Open File Report No.419. National Institute of Advanced Industrial Science and Technology. Research Center for Deep Geological Environments.

43. Lombi E, Donner E, Scheckel KG, Sekine R, Lorenz C, et al. (2014) Silver speciation and release in commercial antimicrobial textiles as influenced by washing. Chemosphere 111: 352-358.

44. Abdel-Halim ES, Al-Deyab SS (2013) One step bleaching process for cotton fabrics using activated hydrogen peroxide. Carbohyd Polym 92: 1844-1849.

45. Glover RD, Miller JM, Hutchison JE (2011) Generation of metal nanoparticles from silver and copper objects: Nanoparticle dynamics on surfaces and potential sources of nanoparticles in the environment. ACS Nano 5: 8950-8957.

46. Litvin VA, Galagan RL, Minaev BF (2012) Kinetic and mechanism formation of silver nanoparticles coated by synthetic humic substances. Colloids and Surfaces A 414: 234-243.

47. Sotiriou GA, Pratsinis SE (2010) Antibacterial activity of nanosilver ions and particles. Environ Sci Technol 44: 5649-5654.

48. Dwivedi AD, Dubey SP, Sillanpää M, Kwon YN, Lee C, et al. (2015) Fate of engineered nanoparticles: Implications in the environment. Coordin Chem Rev 287: 64-78.

49. Silva FM, Pinto RJB, Daniel-da-Silva AL, Trindade T (2014) Cationic release behaviour of antimicrobial cellulose/silver nanocomposites. Cellulose 21: 3551-3560.
50. Bondarenko O, Juganson K, Ivask A, Kasemets K, Mortimer M, et al. (2013) Toxicity of $\mathrm{Ag}, \mathrm{CuO}$ and $\mathrm{ZnO}$ nanoparticles to selected environmentally relevant test organisms and mammalian cells in vitro: a critical review. Arch Toxicol 87: 1181-1200.

51. Li T, Albee B, Alemayehu M, Diaz R, Ingham L, et al. (2010) Comparative toxicity study of $\mathrm{Ag}, \mathrm{Au}$, and $\mathrm{Ag}-\mathrm{Au}$ bimetallic nanoparticles on Daphnia magna. Anal Bioanal Chem 398: 689-700.

52. Kahru A, Dubourguier HC (2010) From ecotoxicology to nanoecotoxicology. Toxicology 269: 105-119.

53. Völker C, Oetken M, Oehlmann J (2013) The biological effects and possible modes of action of nanosilver. Rev Environ Contam T 223: 81-106.

54. Kittler S, Greulich C, Diendorf J, Koller M, Epple M (2010) Toxicity of silver nanoparticles increases during storage because of slow dissolution under release of silver ions. Chem Mater 22: 4548-4554.

55. Griffitt RJ, Luo J, Ao J, Bonzongo JC, Barber DS (2008) Effects of particle composition and species on toxicity of metallic nanomaterials in aquatic organisms. Environ Toxicol Chem 27: 1972-1978.

56. Haulik B, Balla S, Palfi O, Szekeres L, Jurikova T, et al. (2015) Comparative ecotoxicity of the nano $\mathrm{Ag}, \mathrm{TiO} 2$, and $\mathrm{ZnO}$ to aquatic species assemblages. Appl Ecol Env Res 13: 325-338.

57. Binaeian E, Rashidi A, Attar H (2012) Toxicity study of two different synthesized silver nanoparticles on bacteria Vibrio fischeri. World Acad Sci Eng Technol 7 $1219-1225$

58. Navarro E, Baun A, Behra R, Hartmann N, Filser J, et al. (2008) Environmental behavior and ecotoxicity of engineered nanoparticles to algae, plants, and fungi. Ecotoxicology 17: 372-386. 